\title{
Multivariate analysis of bathymetry in the evaluation of reservoirs in Serra Talhada, Pernambuco, Brazil
}

Alan Cézar Bezerra ${ }^{1}$

Renata Akemi Shinozaki-Mendes ${ }^{2}$

Geber Barbosa de Albuquerque Moura ${ }^{3}$

\begin{abstract}
The constant demand for water resources has increased the need for research and adoption of new water use and management practices. In this sense, this work utilizes multivariate cluster analysis to identify the correlation of respective depths of bodies of water in Serra Talhada city, over different periods of rainfall. In order to achieve this, four bathymetric surveys were carried out during one year for three reservoirs within the municipality of Serra Talhada, then cluster analysis and multiple modeling were used to identify the most influential variables on reservoir depth. Based on our results, the multivariate grouping technique can be used to define periods of higher and lower water storage, through bathymetric data, as well as to understand the effects of regional precipitation variability on the water levels of reservoirs. In addition, the generated model indicated a clear influence of the previous month's precipitation on the bathymetry of the reservoirs.
\end{abstract}

Keywords: Cluster analysis. Semiarid. Water resources.

\section{Introduction}

Increasing demand for water resources to meet the need of human consumption, as well as industrial and agricultural uses, has required research and adoption of improved water use practices. These include water resource utilization and management strategies that take advantage of knowledge of the regional physical structure specificities in order to facilitate sustainable water management.

According to Lima et al. (2013), Brazil has several reservoirs that were formed mainly by the damming of rivers in order to meet certain objectives, such as water supply, course regulation, electricity generation, irrigation, navigation and recreation, with the greatest concentration of these reservoirs being constructed in northeastern Brazil in order to meet the specific needs of this region.

In this sense, bathymetry, which is the science of determining depth of bodies of waters such as oceans, seas, lakes, and rivers, can help understanding the dynamics of bodies of water. Once the water depth level information is available, it becomes possible to characterize the physical traits of specific reservoirs, which is a vital tool for evaluating hydrological behavior (CIGAGNA; BONOTTO; STURARO, 2014) in relation to the reserve capacity.

Understanding the dynamics and behavior of reservoirs can help in better reservoir water management and in semiarid and arid regions, which is even more important. Since these regions

1 Universidade Federal Rural de Pernambuco, Unidade Acadêmica de Serra Talhada. Docente. alan.bezerra@ufrpe.br.

2 Universidade Federal Rural de Pernambuco, Unidade Acadêmica de Serra Talhada. Docente. renataasm@gmail.com.

3 Universidade Federal Rural de Pernambuco, Departamento de Agronomia. geber.moura@ufrpe.br. 
have a great variability of frequency and intensity of precipitation, as well as high evaporation rates. In addition, the water supply of cities and agricultural activities depends on the quantity and quality of these waters, which requires constant monitoring and management (BRAGA et al., 2015).

Thus, it becomes possible to envision measures consistent with the current reality of environmental pressures on these bodies of water in order to facilitate the sustainable use of these resources. In this sense, it is necessary to aggregate bathymetric data for the respective bodies of water for analysis by means of multivariate statistical techniques.

Some studies have used multivariate techniques to group together different bodies of water based on hydrochemical parameters in several conditions, such as works developed by Almeída and Frischkorn (2015) and Almeida et al. (2016). However, there are no current studies of bathymetric monitoring of bodies of water which utilize this technique. It is our belief that this application can ensure better monitoring and earlier identification of impacts, such as silting, than traditional analyzes, such as the study carried out in the same region of the present study by Lima and Shinozaki-Mendes (2017).

Therefore, the present work utilizes multivariate analysis to identify the relation between the depths of bodies of water within the municipality of Serra Talhada, in association with different periods of rainfall.

\section{Material and methods}

The bathymetric data was obtained between the years 2010 and 2013 in three reservoirs located in the municipality of Serra Talhada in the state of Pernambuco, Brazil, located at average coordinates of $07^{\circ} 59^{\prime} 07^{\prime \prime} \mathrm{S}$ and $38^{\circ} 17^{\prime} 34^{\prime \prime} \mathrm{W}$ at an altitude of $444 \mathrm{~m}$, and at the semi-arid Brazilian Pajeú microregion (Figure 1). According to Köppen, the climate is typical of the semi-arid region, which is hot and dry, with average rainfall of $657 \mathrm{~mm}$ year ${ }^{1}$ and an average annual temperature of $25.8^{\circ} \mathrm{C}$ (CRUZ NETO et al., 2017).

Figure 1 - Map of Brazil highlighting the state of Pernambuco (A), Map of Pernambuco highlighting Pajeú microregion and Serra Talhada - PE (B), Map of Serra Talhada with Cachoeira, Jazigo and Saco reservoirs (C).

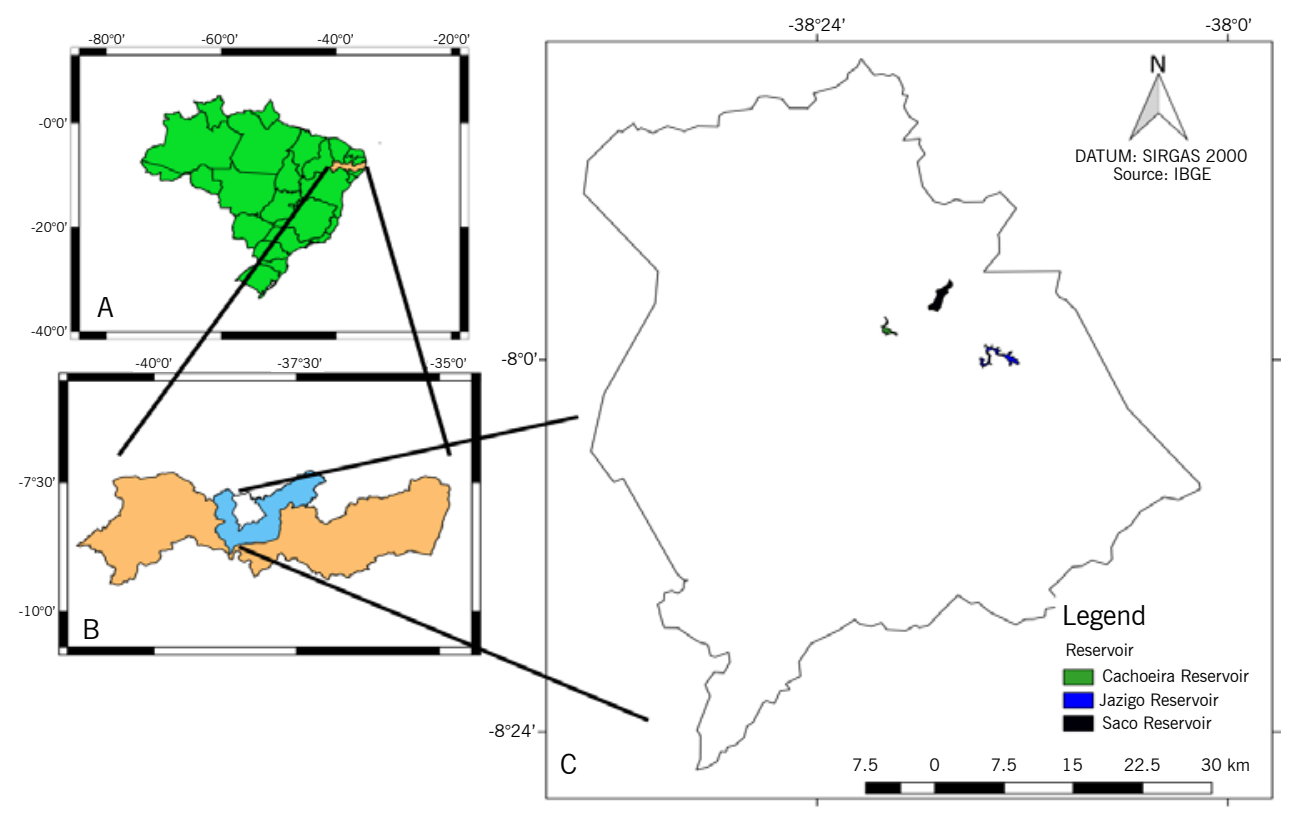

Fonte: Elaborated by the authors (2019). 
Bathymetric survey data was obtained from across the reservoir in zigzag movements from shore to shore, based on a Global Positioning System (GPS), and the location of each reservoir, acquisition dates and amount of points used can be found in Table 1. It was utilized the points inside the reservoirs in order to minimize the effects of the edges and get the depths of the deepest areas. Sonar bathymetric surveys of the reservoirs were carried out using a Garmin Fishfinder 90, Dual-beam $(80 / 200 \mathrm{kHz})$ sonar capable and Maximum depth 182,88 meters, with the aid of a motorized watercraft. Since the analysis in each reservoir considered one year of evaluation, the contribution of sedimentation or silting processes was considered null.

Table 1 - Location and Collection dates on reservoirs in Serra Talhada city, Brazil.

\begin{tabular}{|c|c|c|c|c|}
\hline Reservoirs & Latitude & Longitude & Data Collection Dates & Amount of Points Used \\
\hline Jazigo & $08^{\circ} 0^{\prime} 13^{\prime \prime} \mathrm{S}$ & $38^{\circ} 14^{\prime} 8^{\prime \prime} \mathrm{W}$ & $\begin{array}{c}\text { Sep/2012 } \\
\text { Dec/2012 } \\
\text { Mar/2013 } \\
\text { Jun/2013 }\end{array}$ & 51 \\
\hline Cachoeira & $07^{\circ} 57^{\prime} 57^{\prime \prime} \mathrm{S}$ & $38^{\circ} 19^{\prime} 54^{\prime \prime} \mathrm{W}$ & $\begin{array}{c}\text { Dec/2012 } \\
\text { Mar/2013 } \\
\text { Jun/2013 } \\
\text { Aug/2013 }\end{array}$ & 41 \\
\hline Saco II & $07^{\circ} 55^{\prime} 55^{\prime \prime} \mathrm{s}$ & $38^{\circ} 16^{\prime} 49^{\prime \prime} \mathrm{W}$ & $\begin{array}{c}\text { Sep/2010 } \\
\text { Dec/2010 } \\
\text { Mar/2011 } \\
\text { Jun/2011 }\end{array}$ & 69 \\
\hline
\end{tabular}

Fonte: Elaborated by the authors (2019).

Precipitation data were obtained via the combined rainfall observation stations of IPA (Saco) in Serra Talhada, maintained by the Pernambuco State Agency for Water and Climate (Agência Pernambucana de Água e Clima - APAC). For incomplete data (data loss by the system), supplemental data were obtained from the nearest station of the National Institute of Meteorology (INMET), located at the geographic coordinates $09^{\circ} 23^{\prime} 17.96^{\prime \prime} S$ and $40^{\circ} 31^{\prime 2} 23.74^{\prime \prime} \mathrm{W}$, at an altitude of 373m.

The clustering of similar categories was used as a classification technique in order to identify homogeneous water bodies using the ascending order of depths of all points collected. The choice of this criterion is because it is intended to classify the seasons only.

To utilize the clustering technique, hierarchical grouping criterion was the Ward method, in which the measure of similarity was Euclidean distance. The Ward criterion (1963) allows groups to be created by minimizing dissimilarities or by minimizing the square of the total sum within each group. As such, a grouping of different bodies of water within the study area was carried out, based on the depth, to identify reservoirs with similar depths and at what times of the year these bodies of water present similarities.

The hierarchical grouping technique interconnects samples according to their associations, producing a dendrogram, at which samples are grouped together according to the similarity of chosen variables. This technique is best understood by the principle that greater resemblance is denoted by decreased distance between objects. The cut-off point was determined according to the criterion of half the longest distance, as proposed by Comunello et al. (2013). The multivariate statistic was calculated in $\mathrm{R}$ version 3.4.1, in an integrated Rstudio development environment. 
To analyze the possible influence of the quarter of the year (T1: 1st quarter, T2: 2nd quarter, T3: 3rd quarter, T4: 4th quarter), body of water (JD: Jazigo Reservoir, CR: Cachoeira Reservoir, SR: Saco Reservoir), total rainfall during the month of bathymetry $(P)$ and rainfall during the month prior to bathymetry (PP) in the value of maximum depth (Depth, in meters), the following multiple model (Equation 1) was used (MCCULLAGH, NELDER, 1989):

$$
\text { Depth }=\beta_{0}+\beta_{1} T 1+\beta_{2} T 2+\beta_{3} T 3+\beta_{4} C R+\beta_{5} J D+\beta_{6} P+\beta_{7} P P+\varepsilon
$$

At which: $\beta_{n}$ are the parameters of the model (1), $\varepsilon$ is the error. The quarter variables were inserted as dummy variables, and T4 was not inserted as a variable so that the matrix determinant was not zero. The bodies of water were also inserted with dummy, and SR was not inserted.

To select the significant variables in the model, the stepwise process was used. To evaluate the consistency of the model, the " $F$ " statistic of the variance analysis for regression $(p<0.05)$ and the residual analysis was based on the Durbin-Watson (DW) statistic (DURBIN; WATSON, 1950).

\section{Results and discussion}

When analyzing the depth values (Table 2), the Saco Reservoir presented the highest average values and the greatest variation for the evaluated months while Cachoeira and Jazigo had very similar depth values during the evaluation period. For all the reservoirs, the deepest months is attributed to the precipitation cycle of the region, as there is a tendency for the months with greatest depths to coincide with the heaviest precipitation period for the region (Figure 2).

Table 2 - Mean Depth $(\mathrm{m})$ of bathymetric surveys of the reservoirs in the present study, measured during the period from September 2010 to August 2013.

\begin{tabular}{lcccc}
\hline \multicolumn{5}{c}{ Jazigo Reservoir $(\mathbf{m})$} \\
\hline \multirow{2}{*}{ Average } & Sep/2012 & Dec/2012 & Mar/2013 & Jun/2013 \\
& 6.52 & 4.92 & 3.50 & 6.08 \\
\hline \multirow{5}{*}{ Average } & Cachoeira Reservoir $(\mathbf{m})$ \\
& Dec/2012 & Mar/2013 & Jun/2013 & Aug/2013 \\
\hline \multirow{2}{*}{ Average } & 10.4 & Saco Reservoir $(\mathrm{m})$ & 6.04 \\
& Sep/2010 & Dec/2010 & Mar/2011 & Jun/2011 \\
\hline
\end{tabular}

Fonte: Elaborated by the authors (2019). 
Figure 2 - Monthly precipitation for Serra Talhada during the 2010-2013 research period.

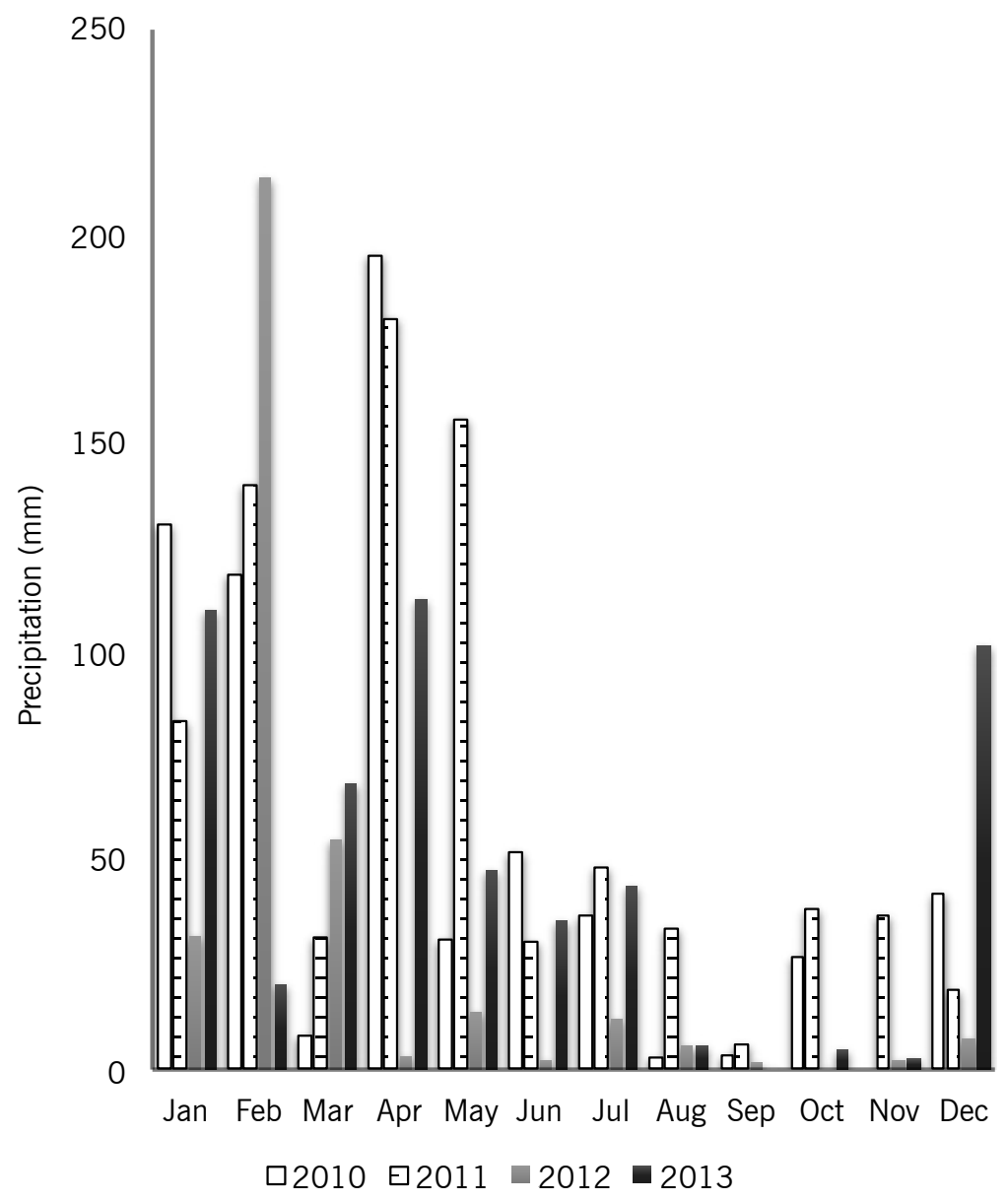

Fonte: Elaborated by the authors (2019).

Next, a more detailed study of each reservoir was carried out in order to determine the monthly similarities. From the cluster analysis of the monthly reservoir data, based on the Euclidian distance and Ward algorithm, the points of class division were determined. For each reservoir, the number of classes was determined to be approximately two, which was adopted for all reservoirs.

Thus, the first reservoir to be studied was the Jazigo, for which the monthly dendrogram is shown in Figure 3. To complement this analysis, a summary of the bathymetric survey statistics is available for the corresponding months. 
Figure 3 - Dendrogram with 4 months of evaluation, as produced from the hierarchical grouping method, for the Jazigo Reservoir.

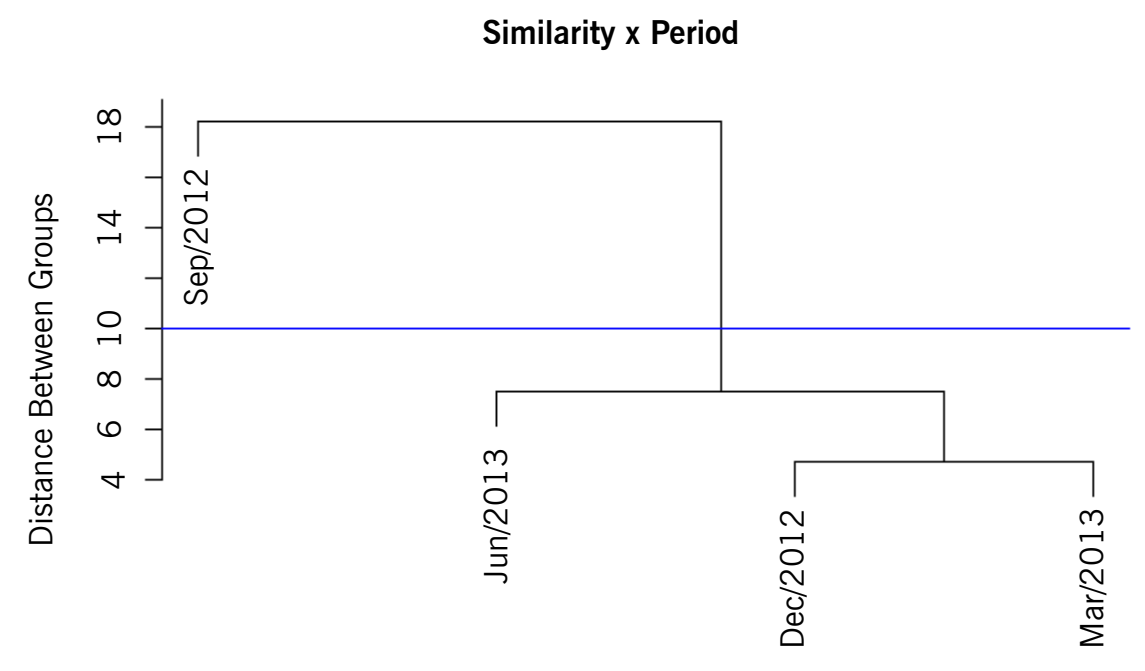

Fonte: Elaborated by the authors (2019).

Based on these results, the four months were divided into two groups, referring to two periods of greater homogeneity. Class A refers to the month of September 2012, as the period of greatest depth, and class B refers to the months of December 2012 and March and June of 2013 as the period of lower depth of the reservoir (Table 2).

The class formations may be related to the prior year's precipitation characteristics and months of bathymetry evaluation. Annual precipitation for 2010 and 2011 was, respectively, $646 \mathrm{~mm}$ and $803 \mathrm{~mm}$, which are close values, each above the historical average of the region (Figure 2). While the accumulated precipitation in 2012 prior to September was $338 \mathrm{~mm}$, about $97 \%$ of the annual precipitation, this period marked the beginning of a drought in the region (MARENGO et al., 2015).

Thus, for the month of December/2012 and March/2013, the term with the most critical values for the evaluation period of this reservoir, the rainfall that occurred during this period was insufficient to significantly increase the reservoir's water level. For June/2013, there is a notable increase in water level due to a greater distribution of precipitation during the months immediately prior to data collection (Figure 2), however, this was not enough to distinguish this evaluation month from the more critical class, as observed in Figure 3.

For the Cachoeira Reservoir, the division of the dendrogram denotes a division into two symmetrical groups (Figure 4). Class A refers to December/2012 and March/2013, which are months with high water levels, while class $B$ refers to months with lower water levels (Table 2).

The first months, which compose group A, flood period, of the Cachoeira Reservoir, present the highest values for the period evaluated probably due to the precipitation of the previous years (Figure 2), especially in the case of 2011, and coinciding with the rainy season (Figure 2). On the other hand, class $\mathrm{B}$, drought period, dendrogram for the Cachoeira Reservoir may have been influenced by the temporal proximity between the evaluated months, even so, it is noticed that for August/2013 there was an increase in water level caused by greater distribution of rainfall in 2013, especially in the month of July, which presented a precipitation of $30 \mathrm{~mm}$. 
Figure 4 - Dendrogram for 4 months of evaluation, resulting from the hierarchical grouping method, for the Cachoeira Reservoir.

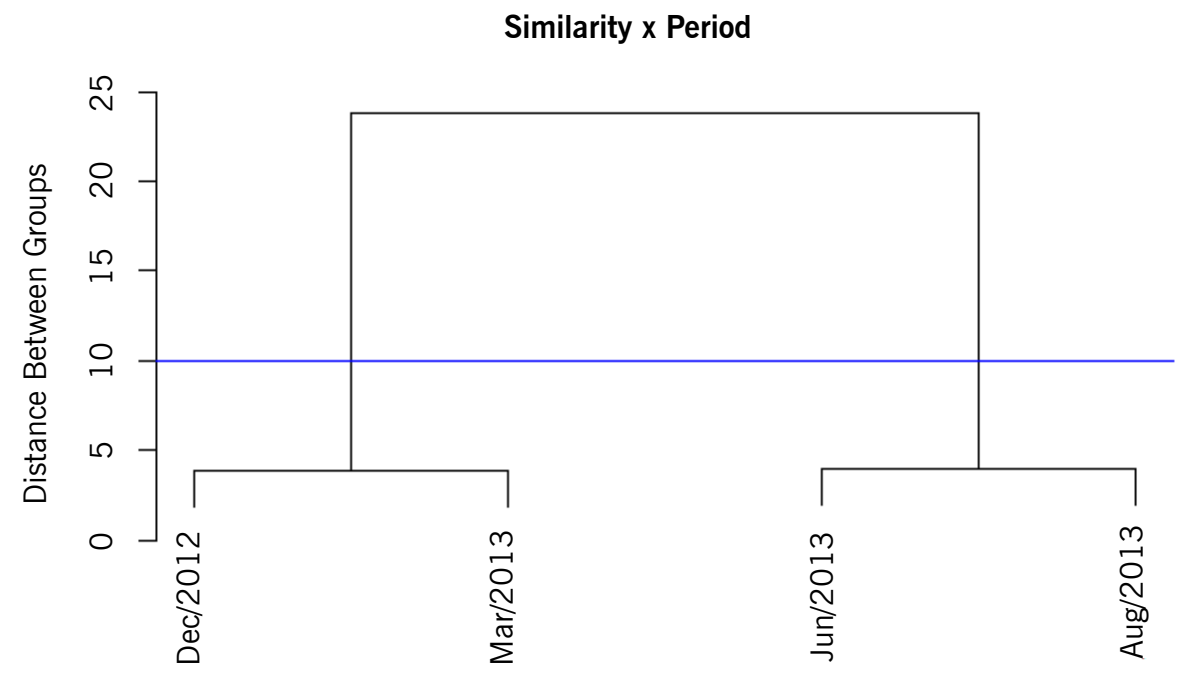

Fonte: Elaborated by the authors (2019).

The grouping analysis for the Saco Reservoir also presents a division into two groups (Figure 5). There is a clear division for Class $A$ of the dendrogram for the Saco Reservoir formed by the month of March/2011, during the period with lower water level, while class B is composed by the months of September and December of 2010 and June of 2011, during the period with higher water levels (Table 2).

Unlike the other reservoirs, in which the months of December and March tended to be grouped into the same class, in the Saco Reservoir the month of March is isolated in class A. This isolation can be attributed to the fact that 2010 was marked by drought while 2011 had greater than average precipitation (MARANGO et al., 2016), but with the rainfall concentrated in the months of March, April and May (Figure 2).

Figure 5 - Dendrogram for 4 months of evaluation, resulting from the hierarchical grouping method, for the Saco Reservoir.

\section{Similarity x Period}

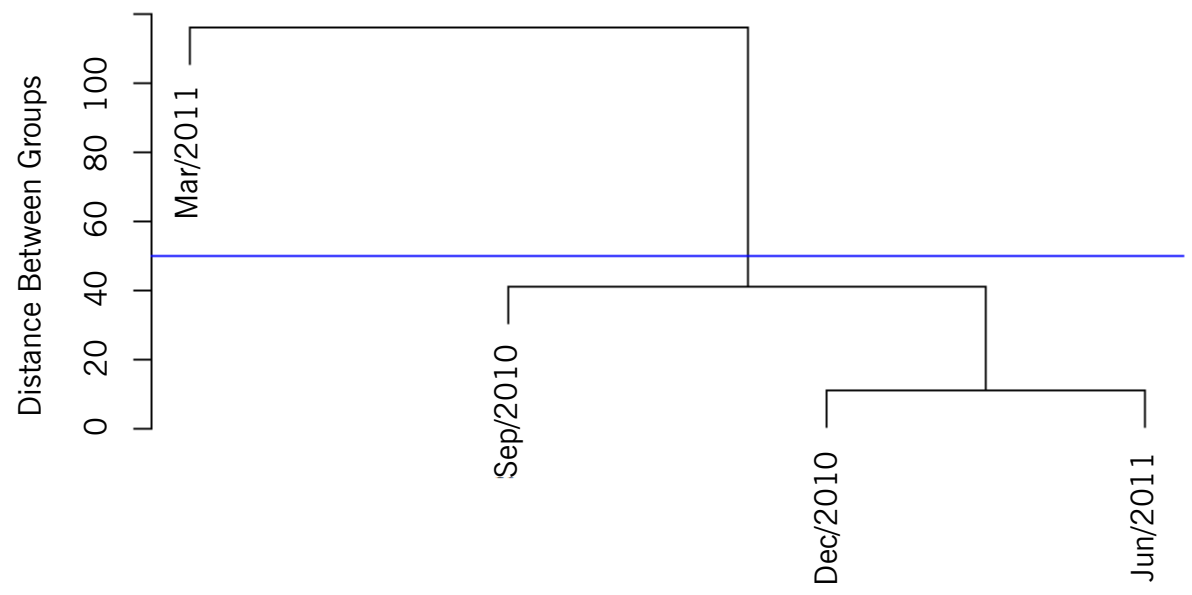

Fonte: Elaborated by the authors (2019). 
In the semiarid region, there is a concentration of rainfall from January to March and May extend until April (COSTA et al., 2017), however, this characteristic was not verified in the separation of the periods in all reservoirs, with the tendency of the rainy season (March) as more critical. As Silva and Tonello (2014) point out, the hydrological behavior of a hydrographic basin can be directly attributed to specific geomorphological characteristics, such as shape, relief and drainage network, soil cover type and vegetation formation.

Thus, in order to complement this study, it is suggested to apply this technique under different conditions, such as years marked by drought, normal rainfall or heavy rainfall. This will make it possible to better separate the periods of higher and lower water storage and thus improve the development and implementation of sustainable water management measures.

In generating a multiple model by stepwise process, the following model (2) was obtained:

$$
\text { Depth }=10.330+0.214 T 1-1.079 T 2-0.840 T 3-1.325 C R-4.336 J D-0.013 P+0.003 P P
$$

With reliability of $0.5542\left(R^{2}\right)$ and a positive correlation ( $\left.D W=1.0945\right)$, the model can be used for estimate depth for the three reservoirs when it cannot be directly measured (different from the Table 2 data that were measured on site).

This model estimates a depth of $10.3 \mathrm{~m}$ for the Saco Reservoir, in the fourth quarter of the year, in the absence of rainfall contributions during the month of bathymetry as well as the month prior. The first quarter of the year presents the greatest volumes, with the lowest values observed in the second and third quarters of the year. The Saco Reservoir presents the greatest depths, followed by the Cachoeira with $1.3 \mathrm{~m}$ less and finally by the Jazigo with $4.3 \mathrm{~m}$ lower water levels. The rainfall of the previous month positively influenced volume, while rainfall during the month of bathymetry had a negligible positive influence.

Utilizing a multiple model makes it possible to more easily obtain values without the need to collect direct data from the field and estimate values which approximate the real values. In case of an on-site measurement, this application also facilitates silting analysis, since a significantly lower actual volume as compared to the estimate may indicate the occurrence of sedimentation in the reservoir. Similarly, a real higher-than-predicted real volume may indicate the occurrence of desorption, allowing a better understanding of the structure and functioning of aquatic environments (LIMA; SHINOZAKI-MENDES, 2017), as well as the application of sustainable management measures for these environments.

\section{Conclusions}

The multivariate clustering technique can be used to define periods of higher and lower water storage from bathymetric data, as well as to understand the effects of regional variability of precipitation in the storage of these reservoirs. It is suggested to the public authorities' greater attention in the management of water resources in the first quarter of year, because it presents itself as more critical. Continuous long-term monitoring is recommended for bodies of water in order to better identify potential sedimentation processes and define sustainable management strategies for the maintenance of these reservoirs. Also, it should be noted that partnerships with government agencies and research institutions are fundamental to the advancement of further analysis and achieving optimal resource outcomes. 


\section{Análise multivariada de batimetria na avaliação de corpos hídricos em Serra Talhada, Pernambuco, Brasil}

\section{Resumo}

A demanda constante por recursos hídricos tem estimulado a pesquisa e a adoção de práticas que visam aperfeiçoar seu uso e sua gestão. Nesse sentido, este trabalho busca identificar a similaridade entre profundidades dos corpos hídricos, em associação à pluviometria, em diferentes períodos, no município de Serra Talhada/PE, por meio da técnica da análise de agrupamento multivariado e modelo múltiplo. Para tanto, foram realizados quatro levantamentos batimétricos durante um ano em cada açude em três açudes do município de Serra Talhada e aplicada uma análise de cluster e uma modelagem múltipla para identificação das variáveis de maior influência na profundidade dos açudes. Com base nos resultados, a técnica multivariada de agrupamento pode ser utilizada para definição de períodos de maior e menor nível de armazenamento de água, a partir de dados batimétricos, bem como perceber os efeitos da variabilidade de precipitação da região no armazenamento desses reservatórios. Além disso, o modelo gerado permitiu comprovar a influência da precipitação nos meses anteriores à batimetria dos açudes.

Palavras-chave: Análise de Cluster. Recursos hídricos. Semiárido.

\section{References}

ALMEIDA, J. B.; BARROS, J. F.; MESQUITA, B. A. D.; SILVA, C. M. S. V.; MENDES FILHO, J.; FRISCHKORN, H.; SANTIAGO, M. M. F. Cluster analysis and geochemical processes for the characterization of the aquifer system in Maracanã/São Luis/MA. Revista Brasileira de Recursos Hídricos (RBRH), v. 21, n. 4, p. 832-840, out./dez. 2016.

ALMEIDA, J. R. F. de; FRISCHKOM, H. Agrupamento da qualidade da água de poços de um pequeno aquífero aluvial: estudo de caso da bacia do riacho Forquilha em Quixeramobimce/Brasil. Revista AIDIS de Ingeniería y Ciencias Ambientales: Investigación, desarrollo y práctica. v. 8, n. 1, p. 114-130, 2015.

BRAGA, G. G.; BECKER, V.; OLIVEIRA, J. N. P. D.; MENDONÇA JUNIOR, J. R. de; BEZERRA, A. F. M.; TORRES, L. M.; GALVÃO, A. M. F.; MATTOS, A. Influence of extended drought on water quality in tropical reservoirs in a semiarid region. Acta Limnologica Brasiliensia, v. 27, n. 1, p. 15-23, 2015.

CIGAGNA, C.; BONOTTO, D. M.; STURARO, J. R. Batimetria e estudo de parâmetros morfométricos do reservatório da floresta estadual "edmundo navarro de andrade" (FEENA) Rio Claro/SP. Geociências, v. 33, n. 4, p. 720-732, 2014.

COMUNELlO, E.; ARAÚJO, L. B.; SENTELHAS, P. C.; ARAÚJO, M. F. C.; DIAS, C. T. S.; FIETZ, C. R. O uso da análise de cluster no estudo de características pluviométricas. Sigmae, v. 2, n. 3, p. 29-37, 2013.

CRUZ NETO, J. F. da; MORAIS, J. E. F. de; SOUZA, C. A. A. de; SOUSA CARVALHO, H. F. de; RODRIGUES, C. T. A.; SILVA, T. G. F. da. Aplicabilidade de indicadores agrometeorológicos para análise do incremento de água por irrigação em sistemas de produção da palma forrageira, cv. Miúda. Journal of Environmental Analysis and Progress, v. 2, n. 2, p. 98-106, 2017. 
DURBIN, J.; WATSON, G. S. Testing for Serial Correlation in Least Squares Regression, I. Biometrika, v. 37, n. 3-4, p. 409-428, 1950.

LIMA, F.; AMANAJÁS, J.; GUEDES, R.; SILVA, E. Análises de Componente Principal e de Agrupamento para estudo de ventos para a geração de energia eólica na região do Ceará, Paraíba, Pernambuco e Rio Grande do Norte, Brasil. Revista Ambiente \& Água, v. 5, p. 188-201, 2010.

LIMA, J. R. C.; SHINOZAKI-MENDES, R. A. Variação sazonal do perfil batimétrico do Açude do Saco, município de Serra Talhada, Pernambuco, Brasil. Revista Agrogeoambiental, v. 9, n. 3, p. 81-92, 2017. Doi: http://dx.doi.org/10.18406/2316-1817v9n32017992.

LIMA, J. R. C.; SHINOZAKI-MENDES, R. A.; ALMEIDA, A. Q. de. Estimativa da batimetria do açude do Saco-PE com auxílio de dados orbitais. Engenharia Agrícola, v. 33, n. 5, 2013.

MARENGO, J. A.; ALVES, L. M.; SOARES, W. R.; RODRIGUEZ, D. A.; CAMARGO, H.; RIVEROS, M. P.; PABLÓ, A. D. Two contrasting severe seasonal extremes in tropical South America in 2012: flood in Amazonia and drought in northeast Brazil. Journal of climate, v. 26, n. 22, p. 9137-9154, 2013.

MARENGO, J. A.; CUNHA, A. P.; ALVES, L. M. A seca de 2012-15 no semiárido do Nordeste do Brasil no contexto histórico. Climanálise, v. 3, p. 1-6, 2016.

MCCULLAGH, P.; NELDER, J. A. Generalized Linear Models, 2nd. Edition, Chapman and Hall: London, 1989.

SILVA, J. L.; TONELLO, K. C. Morfometria da bacia hidrográfica do Ribeirão dos Pinheirinhos, Brotas-SP. Irriga, v. 19, n. 1, p. 103, 2014.

SOUZA COSTA, A. de; BRITO COSTA, W. L. de; BRAGA, C. C.; DANTAS, M. P. Temporal space variability for precipitation in the state of Pernambuco. Journal of Hyperspectral Remote Sensing, v. 7, n. 1, p. 1-7, 2017.

WARD, J. H. Hierarchical grouping of otimize an objetive function. Journal American Statistical Association, v. 58, p. 236-244, 1963.

Received in: April 11, 2019

Accepted in: September 25, 2019 